\title{
Erratum to: Bull Volcanol Volume 73 (2) Special Issue: Failed eruptions: Late-stage cessation of magma ascent
}

The Publisher

Published online: 20 April 2011

(C) Springer-Verlag 2011
Nishimura T, Ueki S (2011) Seismicity and magma supply rate of the 1998 failed eruption at Iwate volcano, Japan. In: Roman DC, Moran SC, Newhall CG (eds) Failed eruptions: Late-stage cessation of magma ascent. Bull Volcanol 73(2):133-142. doi:10.1007/s00445-010-0438-8

Roman DC, Power JA (2011) Mechanism of the 1996-97 non-eruptive volcano-tectonic earthquake swarm at Iliamna Volcano, Alaska. In: Roman DC, Moran SC, Newhall CG (eds) Failed eruptions: Late-stage cessation of magma ascent. Bull Volcanol 73(2):143-153. doi:10.1007/s00445010-0439-7

Taisne B, Tait S, Jaupart C (2011) Conditions for the arrest of a vertical propagating dyke. In: Roman DC, Moran SC, Newhall CG (eds) Failed eruptions: Late-stage cessation of magma ascent. Bull Volcanol 73(2):191-204. doi:10.1007/ s00445-010-0440-1

Crider JG, Frank D, Malone SD, Poland MP, Werner C, Caplan-Auerbach J (2011) Magma at depth: a retrospective analysis of the 1975 unrest at Mount Baker, Washington, USA. In: Roman DC, Moran SC, Newhall CG (eds) Failed eruptions: Late-stage cessation of magma ascent. Bull Volcanol 73(2):175-189. doi:10.1007/s00445-010-0441-0

Moran SC, Newhall C, Roman DC (2011) Failed magmatic eruptions:late-stage cessation of magma ascent. In: Roman DC, Moran SC, Newhall CG (eds) Failed eruptions: Latestage cessation of magma ascent. Bull Volcanol 73(2):115122. doi:10.1007/s00445-010-0444-x

Werner CA, Doukas MP, Kelly P (2011) Gas emissions from failed and actual eruptions from Cook Inlet Volcanoes, Alaska, 1989-2006. In: Roman DC, Moran SC, Newhall CG (eds) Failed eruptions: Late-stage cessation of magma ascent. Bull Volcanol 73(2):155-173. doi:10.1007/s00445-011-0453-4 